UDC 638.154(497.16)

Review paper

doi: 10.5937/AASer1846177B

Acta Agriculturae Serbica, Vol. XXIII, 46 (2018); 177-185

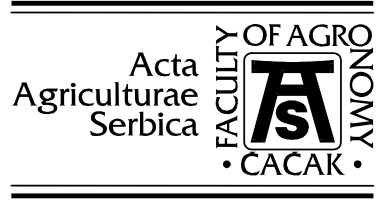

\title{
Measures to protect bee health against varroosis in Montenegro
}

\author{
Mirjana Bojanić-Rašović ${ }^{1 *}$, Vesna Davidović ${ }^{2}$, Mirjana \\ Joksimović-Todorović ${ }^{2}$ \\ ${ }^{1}$ University of Montenegro, Biotechnical Faculty, Mihaila Lalića 1, \\ Podgorica, Montenegro \\ ${ }^{2}$ University of Belgrade, Faculty of Agriculture, Nemanjina 6, Belgrade, \\ Zemun, Serbia \\ *Corresponding author: bojanic.m@t-com.me
}

\begin{abstract}
Varroosis is a disease of bees and their brood caused by Varroa destructor, an ectoparasitic mite (acarine). This parasite is present throughout the year in bee colonies feeding on hemolymph from adult bees, larvae and pupae. Varroosis is also present in the beekeeping of Montenegro. Measures to prevent varroosis include beekeeping on favorable terrains, early detection of diseases, control of newly procured colonies, application of the principles of good beekeeping practice, control of treatment efficiency etc. Diagnostic examination for varroosis is carried out once a year - until the end of March in all bee colonies. For mite control, only registered products should be used. In Montenegro, natural preparations are registered Apiguard (based on thymol) and Api Life Var (based on thymol, eucalyptus oil, camphor and L-menthol). Varroa quickly becomes resistant to synthetic chemical preparations based on compounds, such as amitraz, coumaphos, synthetic pyrethroids - fluvalinate and flumethrin. In addition to gaining resistance, there is a great danger of depositing residues in bee products. Such bee products are a source of contamination for humans through the consumption of bee products (honey, royal jelly, propolis, etc.) and bee wax is a source of contamination through cosmetic products that contain it. Therefore, these synthetic preparations should not be used for the treatment of bee colonies against varroa.
\end{abstract}

Received 13 July 2018 Accepted 16 October 2018 
Keywords: Apis mellifera carnica, honey bee, Montenegro, Varroa destructor, varroosis.

\section{Introduction}

Beekeeping in Montenegro is of great importance for nature conservation as well as for the economic development of Montenegro. Due to the large number of honey herbs, Montenegrin honey is of high quality, both in terms of nutrition and healing properties (Anon. 2014, 2016). In Montenegro, there is an autochthonous race of Apis mellifera var. carnica (kranjska, gray or domestic), which has very good biological and production characteristics (Plavša and Pavlović, 2017). Health care of bees is of great importance for the development of beekeeping. Particular attention is paid to preventing and suppressing contagious and parasitic diseases of bees (Anon. 2016a). In Montenegro, according to the law, the following dangerous diseases included in the OIE list are suppressed: American foulbrood of honey bees, European foulbrood of honey bees, the fungal disease nosemosis and the parasitic diseases: varroosis, acarapisosis, tropilelosis and ethiniosis (Anon. 2017, 2017a). Bee parasites have become a global problem and the cause of dangerous honey bee diseases. The mite Varroa destructor is the most important parasite of bees (Adjalane and Haddad, 2017) (Fig. 1).

Figure 1. Varroa destructor, an ectoparasite of bees 200 x (Bojanić Rašović)

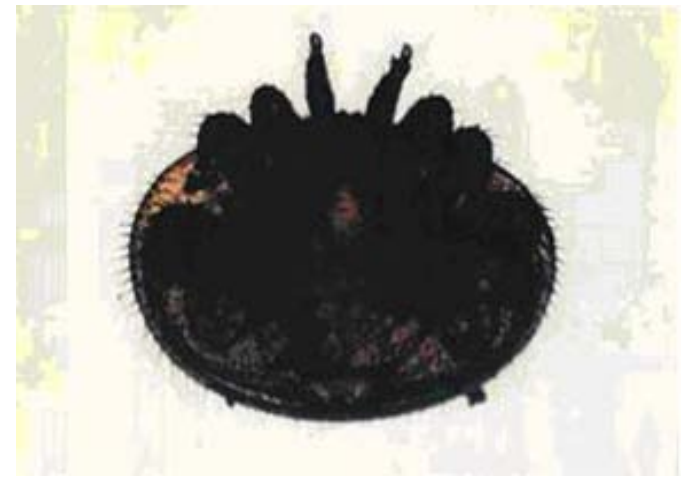

This parasite causes great damage to beekeeping in Montenegro. It provokes varroosis, the disease of bees and their brood. This parasite is present throughout the year in bee colonies by feeding on hemolymphs from bees, larvae and pupae. Direct damage from this parasite is the result of sucking the hemolymph of bees and is manifested by weakening and dying of bees (Anon., 2014; Lolin, 1991). The weakening of the immunity of bees 
infected with $V$. destructor leads to chalkbrood (Getchev and Kantchev, 1998). Indirect damage from this parasite is evidenced by the transmission and spread of viral diseases to bee colonies. It is believed that $V$. destructor contributes to the appearance of the syndrome of bee disappearance (colony collapse disorder) (Adjalane and Haddad, 2017). Parasites on the brood and adult bees can be seen with the naked eye. The parasite leaves the dead bee. The parasitic development begins by laying eggs near the bee larvae in the cell. This development takes place in a closed bee brood simultaneously with the development of the bee brood. Males and females develop in 6-7 and 8-9 days, respectively. After mating, males die, and females remain in the cell feeding on the hemolymph of pupae and young bees (Figure 2).

Figure 2. Varroa destructor on bee pupa (Plavša and Pavlović, 2017)

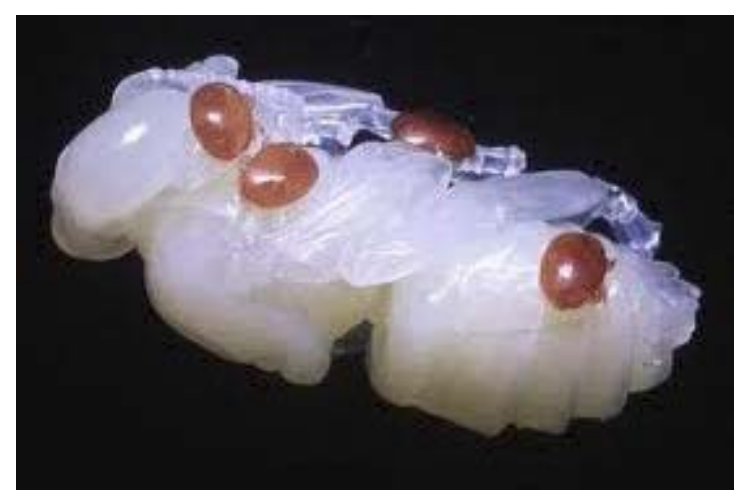

When a young bee comes out of the cell, the parasitic females on its body come out either together with it or by themselves.

Parasites are mostly found in the worker brood in early spring and on the drone in the summer. Clinical signs in a bee colony are only apparent when the parasite invades every third or fourth bee, which leads to growth retardation of young bees, and sudden death of the elderly ones. In young bees, abnormally developed parts of the body, irregular position of the wings and damage to the abdomen are noticed. Infested bees cannot fly, they are restless, crawl into the grass, turn onto their backs and eventually die (Lolin, 1991; Plavša and Pavlović, 2017).

\section{Measures for the prevention and suppression of varroa in Montenegro}

Measures for the prevention of varroosis consist of selecting an adequate locality for the apiary, early detection of the disease, inspection of bee colonies prior to joining, control of newly acquired colonies, control of 
treatment efficacy (Anon, 2018). The biotechnical methods of fighting against varroa involve reducing the number of parasites before and during bee foraging, which is achieved by cutting and removing a drone brood, by setting the construction frame, by removing the first and last worker brood, by separating the worker brood and by forming new colonies, by raising bees resistant to varroa (Stanimirović et al., 2007). It is very important to select the queen bee from bee colonies that are more resistant to $V$. destructor (Muža et al., 2001). In cases of varroosis, the following treatment should be used in infected apiary and in a radius of $3 \mathrm{~km}$ around the apiary: treatment of infected bee colonies at least twice a year - in spring and autumn; removing covered drone larvae from the hive; ban on moving infected bee colonies until the end of treatment. Inadequate application of good beekeeping practices significantly contributes to the appearance and spread of bee diseases (Bojanić Rašović et al. 2016; Bojanić Rašović, 2018).

\section{Diagnosis of varroosis}

The control and prevention of the disease are mostly dependent on the early detection of the presence of varroa mites (Stanimirović et al., 2007). In order to diagnose the disease, if the parasite is present in small numbers on bees, mites that are removed from bees and packed in a well-closed glass container are subjected to laboratory examination (Plavša and Pavlović, 2017). If the parasites are not observed with the naked eye i.e. in suspicious cases, the worker brood and the drone brood are tested in the laboratory in spring and autumn, respectively. Also, about 30-50 live bees from the middle of the nest are placed in a well-closed glass container and submitted for analysis. Laboratory tests can also be performed on debris from the floor of the hive where dead parasites can be found. Also, parasites collected after hive treatment with smoke are tested. Testing is generally performed on debris from hives in winter, on worker and drone brood in spring and summer, and on live bees in autumn. Samples are taken from at least $10 \%$ bee colonies - weaker colonies (Lolin 1991; Plavša and Pavlović, 2017). All apiaries in Montenegro are tested for varroa annually - by the end of March. If it is suspected that bee colonies are invaded by this parasite, diagnostic tests are carried out in other months as well (Anon., 1986, 2018).

\section{Chemical control of varroa}

Varroa can rapidly develop resistance to synthetic chemical compounds, such as amitraz - formamidine, coumaphos, synthetic pyrethroids fluvalinate and flumethrin (Gregorc and Planinc, 2012; Adjalane and Haddad, 2017; Lipiński et al., 2007; Muža et al., 2001). Varroa becomes resistant due to mutations, which help it successfully and quickly adapt to 
new conditions (Lodesani and Costa, 2005). Four years after amitraz treatment, varroa resistance occurs (Adjalane and Haddad, 2017). Varroa which is resistant to tau-fluvalinate develops resistance to other related pyrethroids, such as fluvalinate, flumethrin, acrinathrin. Treatment with amitraz facilitates selection of varroa which is resistant to fluvalinate (Lipiński et al., 2007). In addition to obtaining resistance, there is a high risk of depositing residues in bee products. Such bee products are a source of contamination for humans through the consumption of bee products (honey, royal jelly, propolis etc.); beeswax is a source of contamination through cosmetic preparations containing it (Lodesani and Costa, 2005; Glavan and Božič, 2013). It has also been found that synthetic chemical compounds such as amitraz and fluvalinate negatively impact the immunity of bees by reducing the concentration of lysozyme and other antibacterial proteins (apidocins) in hemolymph of honey bees. Resistance is also reduced by the use of coumaphos based preparations. Bees treated with synthetic preparations are much more sensitive to other diseases (Getchev and Kantchev, 1998). Due to the negative effects of synthetic preparations, natural preparations based on essential oils and organic acids are increasingly used to treat varroa. Because of the low probability of varroa resistance as well as the lack of residues in bee products, natural preparations are a solution for integrated varroa control. In many European countries essential oils of garlic (Allium sativum), tobacco (Nicotiana tabacum), walnuts (Juglans regia) and pine (Pinus sylvestris) are used against varroa. For essential oils to be effective (50-80\%), it is necessary to carry out several treatments in a given time period (Getchev and Kantchev, 1998). Essential oils of majoran (Origanum majorana), thyme (Thymus vulgaris), mint (Mentha piperita) and camphor wood (Cinnamomum camphorae) are also used (Muža et al., 2001).

Thymol, 2-Isopropyl-5-methylphenol obtained from essential oil of thyme (Thymus vulgaris) has a very pronounced acaricidal and fungicidal effect. Concentrated vapors of thymol act on the nervous system of varroa by stopping its growth and reproduction and leading to the inebriation and death of mites. Thymol in small concentrations stops the growth of pathogenic yeasts and molds, thus preventing chalkbrood, nosemosis, American foulbrood of honey bees and European foulbrood of honey bees. The smell of thymol in bee colonies increases the hygienic behavior of bees. On the other hand, high concentrations of thymol vapors can lead to weaker egg laying of the queen bee, death of open brood, loss of queen bee, despoilment, leaving the hive by the bees (Johnson et al., 2010). In Montenegro, currently registered natural preparations include "Apiguard” (based on thymol) and “Api Life Var” (based on thymol, eucalyptus oil, camphor and L-menthol) (Anon. 2018a). Apiguard is a thymol based product and is an effective acaricide, with a low risk of residual appearance in bee products. Its 
efficiency is $76 \%$. This product contains thymol that is released gradually from the gel. Its residues are not stable and do not exceed concentrations found naturally in honey. Apiguard gives better results at a temperature of 15 to $20^{\circ} \mathrm{C}$, and is less efficient at lower temperatures (Gregorc and Planinc, 2012). Apiguard has a better effect during the spring treatment of bee colonies, because during November and December it exhibits lower evaporation due to low air temperature. Its effect is weaker in continental climate conditions (efficiency is below 50\%). Thymovar, a preparation in the form of cellulose strips soaked with thymol, has an efficiency of $85-97 \%$. Thymol-based natural preparations are more effective in suppressing varroa than preparations based on amitraz and fluvalinate. These differences are explained by varroa resistance to synthetic preparations (Gregorc and Planinc, 2012).

Among organic acids, in addition to oxalic acid, formic acid is most commonly used for the treatment of varroa. The efficacy of oxalic acid application is significantly dependent on climatic conditions and ranges from $39 \%$ to $99 \%$, and it should be noted that treatments are performed when there is no brood (Mar Leza et al., 2015). However, negative consequences of long-term treatments with sublethal concentrations of oxalic acid (3.5\%) have been established. These treatments have a negative effect on work ability, health of bees and brood, care of the queen bee, egg laying of the queen bee and longevity. Similar effects are also found for formic acid (Schneider et al., 2012).

When applying preparations for the treatment of varroa, recommendations regarding the period of their application should be followed. This is very important in view of preventing the effects of these preparations on the smell and taste of honey, the appearance of undesirable residue in honey, as well as the degree of their effectiveness in destroying varroa. The efficacy of drugs against varroa is closely related to the ambient temperature during application, air humidity, way of application ( as gas, liquidity, aerosol), concentration of the used substance (Stanimirović et al., 2007). Due to improper application, medicines have a detrimental effect on the life and behavior of bees themselves and their brood and lead to their death. Due to the occurrence of varroa resistance, beekeepers on its own increase doses and concentrations of drugs and use unregistered drugs whose efficacy and toxicity are not adequately tested (Muža et al., 2001). Improving the quality of treatment of bees can be achieved through good and close cooperation of beekeepers with veterinary services. 


\section{Conclusion}

For the purpose of preventing and suppressing varroosis, the state of Montenegro implements statutory measures. To achieve good results, it is very important to appropriately carry out good beekeeping practice. In Montenegro, natural preparations based on essential oils are registered for use against varroa (Apiguard and Api Life Var). Treatment with natural preparations based on essential oils prevents the development of varroa resistance and enables the production of health-safe bee products. This fact gives great opportunities for the development of organic beekeeping in Montenegro. Due to the positive effects of essential oils in controlling varroa, further work should be done to examine their potential applications.

\section{References}

Adjalane N., Haddad N. (2017): Evaluation of the resistance of the mite Varroa destructor to the amitraz in colonies of honey bees (Apis mellifera) in Algeria, Uludag Bee Journal, 17: 1-6.

Anon. (1986): Pravilnik o mjerama za suzbijanje i iskorjenjivanje zaraznih bolesti pčela, Sl.list SFRJ broj 6/86.

Anon. (2014): Sektorska studija za proizvodnju meda. Savez pčelarskih organizacija Crne Gore

Anon. (2016): Zakon o veterinarstvu, Sl. List Crne Gore br. 30/2012, 48/15 i 52/16.

Anon. (2016a): Istraživanje tržišta pčelinjih proizvoda u Crnoj Gori, Savez pčelarskih organizacija Crne Gore, SPOCG

Anon. (2017): Pravilnik o klasifikaciji zaraznih bolesti životinja, načinu prijavljivanja pojave odnosno sumnje i odjavljivanja zaraznih bolesti životinja, Sl. list Crne Gore, broj 92/2017.

Anon. (2017a): Manual of diagnostic tests and vaccines for terrestrial animals (2017), World Organisation for Animal Health (OIE)

Anon (2018): Program obaveznih mjera zdravstvene zaštite životinja u 2018. godini, Sl. list Crne Gore, broj 9/2018.

Anon. (2018a): Veterinarski ljekovi za koje je izdata dozvola za uvoz za period od 01.01.2017 do 31.12.2017, Agencija za lijekove Crne Gore: 1-91 https://www.calims.me (3.07.2018.)

Bojanić Rašović M, Saičić I., Davidović V., Joksimović Todorović M, Relić R. (2016): Application of good manufacturing practice in beekeeping, Proceedings of The International Symposium on Animal Science (ISAS) 2016: 437-442. Faculty of Agriculture, University of Belgrade, Faculty of Agriculture, University of Novi Sad, $24-25$. november, 2016 ..

Bojanić Rašović M. (2018): Zdravstvena zaštita pčela u Crnoj Gori. Pčelarstvo. Savez pčelarskih organizacija Crne Gore: 14-15.

Getchev I., Kantchev K. (1998): Influence of the mite control products on the resistance of the honey bee to chalkbrood. Bulletin of the Veterinary Institute in Puławy, 42, 139-142. 
Glavan G.., Božič J. (2013): The synergy of xenobiotics in honey bee Apis mellifera: mechanisms and effects, Acta Biologica Slovenica, 56 (1): 11-25.

Gregorc A., Planinc I. (2012): Use of thymol formulations, amitraz and oxalic acid for the control of the varroa mite in honey bee (Apis mellifera carnica) colonies. Journal of Apicultural Science, 56 (2): 61-68.

Johnson R.M., Marion D.E., Mullin C.A., Frazier M. (2010): Pesticides and honey bee toxicity - USA. Apidologie, 41: 312-331.

Lipiński Z., Szubstarski J., Szubstarska D. (2007): Detection of the high risk pyrethroid resistant Varroa destructor mites in apiaries of the Walmaiaury province in Poland. Wiadomooeci Parazytologiczne, 53: 245-249.

Lodesani M., Costa M. (2005): Limits of chemotherapy in beekeeping: Development of resistance and the problem of residues. Bee World, 86: 102-109.

Lolin M. (1991): Bolesti pčela, Naučna knjiga, Beograd

Mar Leza M., LladÓ G.., Miranda-Chueca M. (2015): Short communication. Comparison of the efficacy of Apiguard (thymol) and Apivar (amitraz) in the control of Varroa destructor (Acari: Varroidae). Spanish Journal of Agricultural Research 13 (3), e05SC01, 5 pages.

Muža M., Kekez D., Dražić M., Bubalo D., Kezić N. (2001): Djelotvornost razrijeđene mravlje kisjeline na varoozu u pčelinjim zajednicama pri različitim oblicima primjene, Journal of Central European Agriculture, 2, (3-4): 293-301.

Plavša N., Pavlović I. (2017): Bolesti pčela, Univerzitet u Novom Sadu, Poljoprivredni fakultet: 1-134

Schneider, S., Eisenhardt, D. Rademacher, E. (2012): Sublethal effects of oxalic acid on Apis mellifera (Hymenoptera: Apidae): changes in behaviour and longevity. Apidologie, 43 (2): 218-225.

Stanimirović Z., Ćirković D., Pejin I., Pejović D. (2007): Strategija ekološke kontrole u borbi protiv Varroa destructor. Veterinarski Glasnik, 61 (1-2): 11-35. 


\title{
MERE ZDRAVSTVENE ZAŠTITE PČELA OD VAROOZE U CRNOJ GORI
}

\author{
Mirjana Bojanić-Rašović ${ }^{1}$, Vesna Davidović ${ }^{2}$, Mirjana Joksimović- \\ Todorović ${ }^{2}$ \\ 1UniverzitetCrne Gore, Biotehni;ki fakultet, Mihaila Lalića 1, Podgorica, \\ Crna Gora \\ ${ }^{2}$ Univerzitet u Beogradu, Poljoprivredni fakultet, Nemanjina 6, Beograd - \\ Zemun, Srbija
}

\section{Rezime}

Varooza je bolest pčelinjeg legla i pčela koju izaziva ektoparazit, krpelj (akarina) Varroa destructor. Ovaj parazit je prisutan tokom cele godine u pčelinjoj zajednici i hrani se hemolimfom pčela, larvi i lutki. Mere za sprečavanje varooze se sastoje u primeni principa dobre pčelarske prakse, pčelarenju na povoljnim terenima, ranom otkrivanju bolesti, kontroli novonabavljenih društava, kontroli efikasnosti lečenja i dr. Dijagnostičkom ispitivanju na varoozu podležu jednom godišnje - do kraja marta, svi pčelinjaci. Za uništavanje krpelja treba koristiti samo registrovane preparate. U Crnoj Gori su registrovani prirodni preparati - Apiguard (na bazi timola) i ApiLife Var (na bazi timola, eukaliptusovog ulja, kamfora i levomentola. Varoa veoma brzo stiče rezistenciju na sintetičke hemijske preparate na bazi jedinjenja kao što su amitraz, kumafos, sintetički piretroidi - fluvalinat i flumetrin. Osim sticanja rezistencije, postoji velika opasnost od deponovanja rezidua u pčelinjim proizvodima. Takvi pčelinji proizvodi su izvor kontaminacije za ljude preko konzumiranja pčelinjih proizvoda (med, matična mleč, propolis i dr.), a pčelinji vosak predstavlja izvor kontaminacije preko kozmetičkih preparata koji ga sadrže. Zbog toga ova sredstva ne treba koristiti za tretiranje pčelinjih društava protiv varoe.

Ključne reči: Apis mellifera carnica, medonosna pčela, Crna Gora, varooza, Varroa destructor. 